\section{Libraries and librarians needed for international exchanges}

ALA's Joint Committee on International Exchanges is building a database of U.S. and international libraries and librarians interested in international study visits or exchanges. Requests for information and inclusion on the database for and from all countries of the world are welcomed, although in 1992-1994 special attention will be given to visits and exchanges with East/Central Europe and the countries of the former Soviet Union. Librarians considering a study visit abroad are invited to request an input form to be included in the database. Already the Moscow Library Association, the National Library of Romania, the Library and Technical University of Budapest, the University Library at the Lajos Kosuth University in Debrecen (Hungary), the National Library of Prague, and the National University Library of Macedonia have offered to host American librarians. Committee members are prepared to act as go-betweens and to assist those interested in finding sources of financial support.

The committee has received letters from Czechoslovakia, Bulgaria, Hungary, Romania, and the Commonwealth of Independent States such as this from Lyubov, a reference librarian in a science library, "Neither we nor our children will live to see the society we are trying to built today. So I dream to see America - country of the future, as I imagine it."

For more information contact Opritsa Popa, chair, ALA IRC/IRRT Joint Committee on International Exchanges, University of California, Davis, Shields Library, Davis, CA 95616.

\section{Reference help available on the Internet}

Need help answering a difficult reference question? "Stumper L" may be able to help. Students at Rosary College's Graduate School of Library and Information Science are operating a listserv on the Internet. Librarians can send in questions they need help finding answers to and the graduate students send the questions on to the over 500 librarians in 5 countries that subscribe. The subscribers then respond directly to the questioners using the Internet.

Questions sent to "Stumper L" have included "What state driver educational manuals allow advertising?" "How can one make a native American dream catcher?" and "What is the origin of the phrase "run-of-the-mill'?" To subscribe to the service send the message "Sub Stumper L (your name)" to Mail-serv@crf.cuis.edu.

\title{
Making the most of your serials budget
}

During the past four years of increased serials prices coupled with decreased institutional budgets and statewide funding, the University of Massachusetts Medical Center Library (UMMCL) has been able to increase subscriptions from about 2,100 to 2,500 titles. Two approaches made this $20 \%$ increase possible.

First, the policy of using only one subscription agent was evaluated and abandoned. Surveys showed that: 1) some publishers gave $10-55 \%$ discounts with no added service charges; 2) some domestic subscription agents added 3.5-4.9\% service charges for all titles; 3) some domestic book dealers supplied domestic continuations at $12-15 \%$ discounts; and 4) some foreign subscription agents discounted foreign titles 3.5-5.0\%. Because of these findings, subscriptions were redirected as follows: foreign serials to a foreign agent; discounted domestic titles to the publishers; non-discounted domestic titles to publishers whose total annual subscription costs ex- ceeded $\$ 10,000$; domestic continuations to a book dealer; and remaining titles to a domestic agent.

Second, the need for subscriptions by some of the Medical Center's revenue-generating components was brought to the attention of administrative units. Potential cuts in subscriptions were equated with potential cuts in abilities to provide quality patient care and perform important basic research. As a result, supplemental funds were appropriated in order to maintain and add titles.

Thus, during a period when many academic libraries had to reduce subscription levels, the UMMCL was able to keep pace with the ever-increasing volume of scientific periodical literature. Testifying to the value of this information, the library now supplies over 2,000 interlibrary loan articles per month to its region of the country.-Donald Morton, University of Massachusetts Medical Center Library 